\title{
Research Article: Assessment of constraints and strategies for goats rearing to increase income in district Mahoba
}

\section{Sudhir Kumar Rawat}

Article Chronicle: Received :

03.03.2019;

Revised :

16.04.2019;

Accepted :

17.05.2019

KEY WoRdS:

Bundelkhandi goat,

Constraints,

Productive traits, Rearing system,

Strategies

Author for correspondence :

Sudhir Kumar Rawat

Krishi Vigyan Kendra,

Hathras (U.P.) India

Email:sudhirkvk@

gmail.com
SUMMARY : The present study was conducted in Mahoba district of Bundelkhand region of Uttar Pradesh. This region is most suited for rearing of Bundelkhandi goats due to natural habitat and special survival characteristics in the species. A sample of 240 farmers and their 566 buck and 1254 doe were randomly selected from all four blocks. The respondents were interviewed with the help of well structured interview schedule. The study covered daily milk yield per day, lactation length (days), total lactation milk yield (Baruwa, 2013), as higher under semi-intensive condition than intensive condition and extensive condition. Maximum goat keepers 63.96 per cent reared goats in semi-intensive system, mostly 74.36 per cent is a grazing method utilized by farmers in Mahoba. In Mahoba that lack of credit 81.67 per cent and inadequate veterinary service 78.33 per cent were the major constraints asked for goat farmers. Farmers suggest some possible solutions to the problems as development grazing land 89.58 per cent and provide veterinary facilities 78.33 per cent in Mahoba. Semi-intensive systems can be profitable at rural areas in Mahoba district.

How to cite this article : Rawat, Sudhir Kumar (2019). Assessment of constraints and strategies for goats rearing to increase income in district Mahoba. Agric. Update, 14(2): 148-154; DOI : 10.15740/HAS/AU/14.2/ 148-154. Copyright@ 2019: Hind Agri-Horticultural Society. 